\title{
Symposium Report
}

\section{The stomach: factors of importance to the anaesthetist}

\author{
Participants \\ J.M. Davies MSc MD FRCPC (Chairman) \\ Department of Anaesthesia, Foothills Hospital at the \\ University of Calgary. Calgary. Alberla \\ Joseph S. Davison PhD \\ Department of Medical Physiology, University of \\ Calgary, Calgary, Alberla T2N 4NI \\ (Applied physiology of gastrointestinal functions) \\ Walter S. Nimmo MD FRCP FFARCS FFARACS \\ Inveresk Clinical Research, Edinburgh EHI4 4AP, \\ Scotland. \\ (Pharmacology of agents that affect gastric secretion, \\ emplying and vomiting) \\ Jean-François Hardy MD FRCPC \\ Department of Anaesthesia, Institut de Cardiologie de \\ Montréal. Université de Montréal, 5000 est Belanger, \\ Montréal, Québec HIT IC8 \\ (Regurgitation and aspiration in the non-pregnant pa- \\ tient: pathophysiology, incidence, and prophylaxis) \\ Geraldine O'Sullivan MD FFARCS \\ Department of Anaesthetics, St. Thomas' Hospital, \\ London SEI 7EH England \\ (Regurgitation and aspiration in the pregnant patient: \\ pathophysiology, incidence, and prophylaxis) \\ J.R. Maltby MB BChir FFARCS FRCPC \\ Department of Anaesthesia, Foothills Hospital at the \\ University of Calgary, Calgary, Alberta. \\ (The shortened fluid fast and the Canadian Anaesthe- \\ tists' Society's new guidelines for fasting in elective/ \\ emergency patients)
}

\section{Overview}

The title of the Ninth Annual Anaesthetic Symposium of the Department of Anaesthesia, Foothills Hospital at the University of Calgary was "The Stomach: Factors of Importance to the Anaesthetist." The purpose of the symposium was to review the latest in gastric physiology and pharmacology, i.e., regurgitation, vomiting, and pulmonary aspiration of gastric contents. In addition, the latest guidelines to the preoperative fasting were discussed.

Dr. Joe Davison discussed the physiology of the stomach, describing how gastrin secretion and downward and upward emplying occur. He emphasized that advances in the understanding of the basic processes have led to the development of specific therapy. For example, gastric secretion is under the control of gastrin, acetylcholine, and histamine, with the latter as the final common denominator. Dr. Walter Nimmo followed with a description of current and soon-to-be-introduced drug for the treatment of problems of gastric secretion and emptying, and nausea and vomiting. He also introduced a literary note to the symposium by describing how delay in gastric emptying due to the effect of opioids had been used by Agatha Christie in the 1920's as a plot device in "The Mysterious Affairs at Styles." Dr. Jean-Francois Hardy reviewed the problem of regurgitation and aspiration in the non-pregnant patient. He then defined the factors which place a patient at risk of these pulmonary complications. These factors include the composition of gastric fluid and bile, the force of retrograde profusion, degree of incompetence of the lower oesophageal sphincter, and the volume of liquid (sufficient to inundate the lungs). Dr. Geraldine O'Sullivan reviewed these problems in the pregnant patient. She also outlined trends in the incidence of matemal mortality associated with anaesthesia: although the absolute numbers of deaths has decreased, the proportion of those dying from difficulties with tracheal intubation has increased. Finally, Dr. Roger Maltby described the rationale for the past, present, and future guidelines for preoperative oral intake. He noted that fasting has no effect on either lower oesophageal tone (rarely a cause of problems) or protective upper airway reflexes (commonly abolished by the use of the tracheal tubes, muscle relaxants, and deep anaesthesia). In conclusion, all speakers emphasized the importance of identifying patients at risk of complications.

Le thème du 9ème Symposium Annuel d'Anésthésie du 
département d'Anesthésie du Foothills Hospital de l'Université de Calgary était " "L'estomac: Facteurs importants pour l'anesthésiste ». Le but de ce Symposium était de revoir les dernières données de physiologie et de pharmacologie gastrique, i.e., régurgitation, vomissement et aspiration pulmonaire du contenu gastrique. En plus, les dernières directives quand au jeûne préopératoire furent discutées.

Le Docteur Joe Davison a discuté la physiologie de l'estomac, a expliqué la sécrétion de la gastrine ainsi que la vidange gastrique normale et anormale. Il a mis l'emphase sur les nouvelles connaissances quand au processus de base qui ont conduit au développement de thérapies spécifiques. Par exemple, la sécrétion gastrique qui est sous le contrôle de la gastrine, de l'acétylcholine et l'histamine, ce dernier étant le dénominateur commun final. Le Docteur Walter Nimmo a suivi avec une description des médicaments disponibles actuellement et ceux qui le seront bientôt pour le traitement des problèmes de sécrétions et de vidange gastrique, des nausées et des vomissements. Il a aussi amené une note littéraire à ce Symposium en décrivant comment le délai de la vidange gastrique dû aux effets des opiacés a été utilisé par Agatha Christie en 1920 comme une clé de mystère dans son livre "The Mysterious Affairs at Styles". Le Docteur JeanFrançois Hardy a revu le problème de régurgitation et d'aspiration chez la patiente non enceinte. Il a aussi définit les facteurs qui expose la patiente au risque de ses complications pulmonaires. Ces facteurs incluent la composition du liquide gastrique et de la bile, la force du jet rétrograde, le degré d'incompétence du sphincter œsophagien inférieur et le volume du liquide (suffisant pour inonder les poumons). Le Docteur Géraldine O'Sullivan a revu ces problèmes chez la patiente enceinte. Elle a aussi revu les tendances dans les incidences de la mortalité maternelle associées á l'anesthésie. Même si le nombre absolu de décès a diminué, la proportion de celles qui meurent à cause de difficultés d'intubation trachiale a augmenté.

Finalement, le Docteur Roger Maltby a décrit la logique derrière les directives passées, présentes et futures concernant le jeûne pré-opératoire. 11 a noté que le jeûne n'avait aucun effet sur le tonus du sphincter oesophagien inférieur (rarement à cause des problèmes) ou les réflexes de protection des voies aériennes supérieures (habituellement abolies par les tubes endotrachéaux, les relaxants musculaires et l'anesthésie profonde). En conclusion, tous les conférenciers ont mis l'emphase sur l'importance de l'identification des patients à risque de complications.

\section{Acknowledgements}

I gratefully acknowledge Sharon Hodgkinson for her help in preparation of the summaries; Jocelyn Lockyer and her staff at Continuing Medical Education, Faculty of Medicine, University of Calgary for organizational help; and Anaquest, Arrow, Burroughs Wellcome, Cook (Canada) Inc., Graphic Controls, and Janssen Pharmaceutics for generous grants in aid of Continuing Medical Education.

\section{Applied physiology of gastrointestinal functions}

The gastrointestinal tract can be a major factor in contributing to morbidity and even mortality after anaesthesia. These complications may be due to the anaesthetic or interactions between the anaesthetic and other factors such as drugs administered pre- and postoperatively, the effects of surgery, or the physiological state of the patient. Some, but not all, of the complications of gastrointestinal origin can be fully explained by current knowledge of gastrointestinal physiology and pharmacology. In other cases basic physiological principles can point the way to further studies.

\section{Regurgitation and vomiting}

Pulmonary aspiration of gastric contents is a major potential hazard of anaesthesia. In obstetrics, anaesthesia is a leading cause of maternal mortality, with aspiration of gastric fluids the most common cause of anaestheticrelated maternal death. ' The pregnant patient is particularly vulnerable to aspiration for several reasons which all contribute to an increased susceptibility to regurgitation. These include: lowered barrier to gastric reflux because of reduced lower oesophageal sphincter tone; $;^{2}$ delayed gastric emptying, at least in those patients with heartburn; ${ }^{3,4}$ and augmented gastric secretion, ${ }^{5}$ possibly due to increased circulating gastrin concentrations. ${ }^{6}$

During labour, additional factors potentiate the tendency to regurgitation. Gastric emptying is delayed in the later stages of labour,,$^{3,4}$ possibly because of pain and stress. Use of drugs such as opioids and sedatives further retards gastric emptying ${ }^{7}$ in many, if not in all cases, through action on the enteric system. In addition, gastric secretion is increased because of starvation ketosis.'

While problems of regurgitation and subsequent aspiration in pregnancy are mainly attributable to motility 